\title{
HOXA1 1 and MMP2 gene expression in uterosacral ligaments of women with pelvic organ prolapse
}

\author{
Nafiye Yılmaz', Gülnur Ozaksit ${ }^{1}$, Yunus Kasım Terzi², Saynur Yılmaz', Burcu Budak', Orhan Aksakal', Feride Iffet Şahin ${ }^{2}$ \\ 'Dr. Zekai Tahir Burak Women's Health Education and Research Hospital, Ankara, Turkey \\ ${ }^{2}$ Department of Clinical Genetics, Basskent University Faculty of Medicine, Ankara, Turkey
}

\section{Abstract}

Objective: Pelvic organ prolapse (POP) is a common disorder that negatively impacts the quality of life in many women. Uterosacral ligaments (USLs) are supportive structures of the pelvic organs that are often attenuated in women with POP. The HOXA genes regulate the development of the uterosacral ligaments. We compared expression of HOXA11 and MMP2 in USLs of women with and without POP.

Material and Methods: A prospective sequential cross sectional study was conducted in ZTB Women's Health Research and Education Hospital. We compared expression of HOXA11 and MMP2 in USLs of women with (n:18) and without (n: 15) POP.

Total RNA was isolated from patient (n:18) and control (n:15) uterosacral ligament tissues with TriPure isolation reagent according to the manufacturer's instructions. Expression levels of HOXA11 and MMP2 were determined using semiquantitative RT-PCR in a Light Cycler 480 system. Real-time ready catalog assays, which are short FAM-labeled hydrolysis probes containing locked nucleic acid, were used for RT-PCR reactions.

Results: There was no difference in patients' mean age, parity, body mass indexes, and menopausal status between two groups. Means of RNA expression of MMP2 were $1.27 \pm 0.6$ and $0.75 \pm 0.4$ in the POP group vs control group, respectively (p:0.007). Means of RNA expression of HOXA 11 were $2.57 \pm 2.4$ and $1.94 \pm 1.4$ in the POP group vs control group, respectively (p:0.376). The POP group was divided as mild and severe POP; there was no difference in HOXA11 and MMP2 RNA expression between groups ( $p>0.05)$.

Conclusion: Although there was no difference HOXA11 RNA expression in USLs with the POP group vs control, there was a significant difference MMP2 RNA expression in USLs with the POP group vs control. There are limited studies on this subject, and study results are contradictory. Further investigations with larger numbers of cases are needed to clarify this subject. (J Turk Ger Gynecol Assoc 2014; 15: 104-8)

Key words: HOXA11, MMP2, pelvic organ prolapse

Received: 06 May, $2014 \quad$ Accepted: 07 May, 2014

\section{Introduction}

Uterosacral ligaments (USLs) are the principal support structure of the uterus and vagina. Weakness of these structures and fascial support of the distal genital tract results in pelvic organ prolapse (POP) (1). In women, POP affects the quality of life negatively. It usually presents with urinary and fecal incontinence, pelvic pain, and sexual dysfunction due to disruption of the pelvic anatomy (2). The reported prevalence of POP is around $40 \%$ in the female population. Approximately $11-30 \%$ of patients who are managed surgically experience recurrent prolapse and are reoperated (3).

Despite the great amount of knowledge about the growth and differentiation of the reproductive tract, we have very little information regarding the molecular pathways of the development of the USL. The uterosacral ligaments are condensed bands of tissue formed from the endopelvic fascia attached to the posterior uterine cervix and the anterior face of the sacrum (4).

Studies report differentially expressed extracellular matrix (ECM) proteins in uterosacral ligaments and vaginas from women with pelvic organ prolapse (POP) (4-10). Gene expression patterns, including Hox/HOX, modulate the ECM (11). Particularly, HOXA11, which regulates collagen and matrix metalloproteinase (MMP) expression, has a primary role in the development of the lower uterine segment and cervix.

Proteinases secreted by connective tissue cells corrupt collagen. The MMPs are a group of proteinases that degrade the extracellular matrix and components of the basement membrane (12). Type IV collagen, a primary component of the basement membrane, is degraded by MMP-2 $(13,14)$. Thus, it may be postulated that elevation of MMP-2 expression may lead to progression of POP. Recent studies show that HOXA11 expression was decreased in patients with pelvic organ prolapse $(15,16)$. The aim of the current study was to compare expression of HOXA11 and MMP2 in USLs of women with and without POP.

\section{Material and Methods}

A prospective sequential cross-sectional study was performed with a total of 33 women. This study was approved 
by the local ethics committee and institutional review board of the Zekai Tahir Burak Women's Health Education and Research Hospital and the Başkent University Faculty of Medicine (Project no: KA11/47). Written informed consent was obtained from all volunteers. The ethical principles for medical research involving human subjects enunciated in the 18th World Medical Association Declaration of Helsinki were applied. All patients were evaluated for the presence of pelvic prolapse according to the quantification system advocated by the International Continence Society (17). Women with stage II POP or greater were assigned to the POP group. Eighteen women were diagnosed with POP - mild POP (stage 2), (n:9) and severe POP (Stage 3-4), (n:9) - and underwent vaginal hysterectomy, while 15 women were established with benign gynecologic disorders and underwent total abdominal hysterectomy. Women with systemic disease, previous pelvic surgery, hormone use, or obesity were excluded from the study.

Specimens were collected from women undergoing vaginal or abdominal hysterectomy at our institution. Data regarding age and parity were recorded. At the time of surgery, $5 \mathrm{~mm}$ samples of the USLs were taken from the proximal ligament at its insertion into the cervix, where the ligament is consistently identifiable.

\section{Real-Time PCR Analysis}

Total RNA was isolated from 18 patient and 15 control uterosacral ligament tissue samples with TriPure isolation reagent according to the manufacturer's instructions (Roche Diagnostics GmbH, Mannheim, Germany). The quality and quantity of RNA were determined with a NanoDrop 2000 Spectrophotometer (Thermo Scientific, Wilmington, DE, USA). One microgram of total RNA was reverse-transcribed using the Transcriptor First-Strand cDNA Synthesis Kit (Roche Diagnostics $\mathrm{GmbH}$, Mannheim, Germany). Real-time ready catalog assays, which are short FAM-labeled hydrolysis probes containing locked nucleic acid, were used for RT-PCR reactions (Roche Diagnostics GmbH, Mannheim, Germany). Expression levels of homeobox A11 (HOXA11) and matrix metallopeptidase 2 (MMP2) were determined using semiquantitative RT-PCR with a Light Cycler 480 II system (Roche Diagnostics GmbH, Mannheim, Germany) according to the manufacturer's instructions with a pre-incubation step at $95^{\circ} \mathrm{C}$ for 10 minutes, followed by 45 cycles at $95^{\circ} \mathrm{C}$ for 10 seconds, $60^{\circ} \mathrm{C}$ for 30 seconds, and $72{ }^{\circ} \mathrm{C}$ for 1 second. Semiquantitative PCR reactions were run in triplicate. The relative expression levels of HOXA11 and MMP2 transcripts were calculated by the threshold cycle $(\mathrm{Ct})$ and the 2-ddCt method using beta-actin (Roche Diagnostics $\mathrm{GmbH}$, Mannheim, Germany) as the housekeeping gene (18).

\section{Statistical Analysis}

SPSS Statistical 17 package (SPSS Inc., IL, Chicago, USA) program was used for statistical analysis of the data. Descriptive statistics were expressed as mean \pm standard deviation for patient and control groups. According to these values, significance levels were calculated with independent samples t-test for determining MMP9 and HOXA11 gene expression status.

\section{Results}

Table 1 shows the clinical characteristics and gene expressions of the groups. There were no statistically significant differences in age and parity between groups (p:0.076 and 0.5214, respectively). Means of RNA expression of MMP2 were $1.17 \pm 0.5$ and

Table 1. HOXA11 and MMP2 means of all groups

\begin{tabular}{|l|c|c|c|}
\hline & POP (n:18) & Control (n:15) & p \\
\hline Mean age & $56.44 \pm 4.5$ & $53.46 \pm 12.15$ & 0.076 \\
\hline Parity & $4.0 \pm 1.7$ & $3.9 \pm 2,8$ & 0.935 \\
\hline HOXA11 & $2.57 \pm 2.4$ & $1.94 \pm 1.4$ & 0.376 \\
\hline MMP2 & $1.27 \pm 0.6$ & $0.75 \pm 0.4$ & 0.007 \\
\hline $\begin{array}{l}\text { POP: pelvic organ prolapse } \\
\text { p<0.05 is significant }\end{array}$ \\
\hline
\end{tabular}

Table 2. Review of the literature

\begin{tabular}{|c|c|c|c|c|}
\hline Author & Subject & Tissues (studied) & Parameters & Finding \\
\hline Connel 2009 (3) & 22 patients & USLs & $\begin{array}{l}\text { HOXA11 gene expression } \\
\text { and cell proliferation in } \\
\text { USLs }\end{array}$ & $\begin{array}{l}\text { Decreased cell proliferation } \\
\text { and HOXA1 } 1 \text { gene } \\
\text { expression in patients with POP }\end{array}$ \\
\hline Strinic 2009 (37) & $\begin{array}{l}40 \text { patients with POP } \\
40 \text { Control }\end{array}$ & USLs & MMP1 and MMP2 & $\begin{array}{l}\text { Increased MMP1 expression } \\
\text { Unchanged MMP2 levels }\end{array}$ \\
\hline Connel 2008 (14) & $\begin{array}{l}18 \text { patients with POP } \\
10 \text { Control }\end{array}$ & USLs & $\begin{array}{l}\text { HOXA11 gene expression, } \\
\text { MMP 2, MMP9, Collagen } 1 \\
\text { and Collagen } 3\end{array}$ & $\begin{array}{l}\text { Decreased HOXA1 } 1 \text { expression, } \\
\text { Decreased collagen } 1 \text { and } 3 \text {, } \\
\text { Increased MMP2 expression }\end{array}$ \\
\hline Wieslander 2007 (39) & mice & Vaginal tissue & MMP2, MMP9, MMP12 & $\begin{array}{l}\text { MMP2 and MMP9 expression } \\
\text { increased postpartum }\end{array}$ \\
\hline Phillips 2006 (5) & $\begin{array}{l}14 \text { patients with POP } \\
14 \text { Control }\end{array}$ & $\begin{array}{l}\text { USLs } \\
\text { Vaginal tissue }\end{array}$ & MMP2 and MMP9 & $\begin{array}{l}\text { Increased MMP2 in vaginal tissue } \\
\text { Unchanged MMP2 levels in USLs }\end{array}$ \\
\hline Gabriel 2006 (4) & $\begin{array}{l}17 \text { patients with POP } \\
18 \text { Control }\end{array}$ & USLs & MMP1 and MMP2 & $\begin{array}{l}\text { Increased MMP2 expression } \\
\text { Unchanged MMP1 levels }\end{array}$ \\
\hline
\end{tabular}




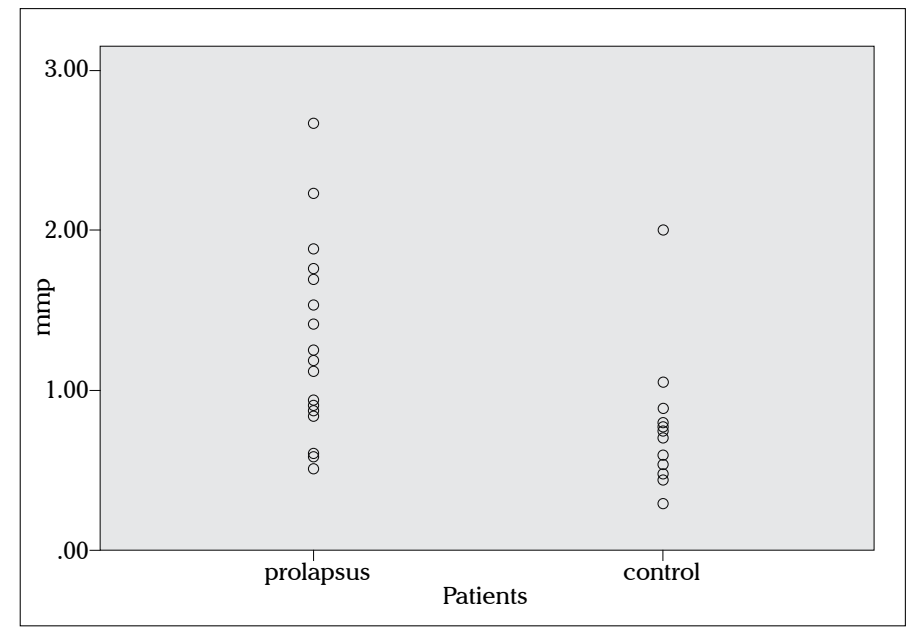

Figure 1. MMP 2 levels in USLs from women with and without POP

$0.7 \pm 0.3$ in the POP and control groups, respectively (p:0.003). Means of RNA expression of HOXA11 were $2.12 \pm 1.9$ and $1.79 \pm 1.3$ in the POP and control groups, respectively (p:0.487) (Table 1). The distribution of MMP2 and HOXA11 gene expression values is seen in Figures 1 and 2. There was no significant difference of HOXA11 and MMP2 RNA expression between the mild and severe POP groups, mild vs control, or severe vs control groups.

\section{Discussion}

The incidence of pelvic prolapse is very high, and it is related to multiparity, age, and obesity but may occur in the absence of these risk factors; the pathophysiology of pelvic prolapse is still obscure $(19,20)$. However, nulliparous women without any risk factors may also develop POP. Therefore, a genetic predisposition may play a role as well (21-23).

Regulation of proliferation and cell death, which is controlled by the action of various different genes, is necessary for normal development and function of tissues (24). Cellular proliferation and apoptotic responses are regulated by HOXA11 in the developing uterus and the USLs $(24,25)$. In human and mice studies, this gene has been demonstrated to be functional in adult life and is believed to have a principal role in providing the plasticity of the uterus during different phases of the menstrual cycle and pregnancy $(25,26)$.

We evaluated 18 women with POP and 15 women with normal pelvic support in this study. There was no difference in patient mean age, parity, or menopausal status between the two groups. We have demonstrated increased MMP-2 expression in the USLs of women with POP, a finding consistent with prior studies. On the other hand, we did not find a statistically significant difference in expression of HOXA11 in patients with POP vs. controls.

Matrix metalloproteinases are secreted as an inactive form (27) and are capable of degrading extracellular matrix essential in normal and pathologic tissue remodeling processes (28-34). Recent evidence suggests that changes in connective tissue composition are at least partially involved in the pathophysiol-

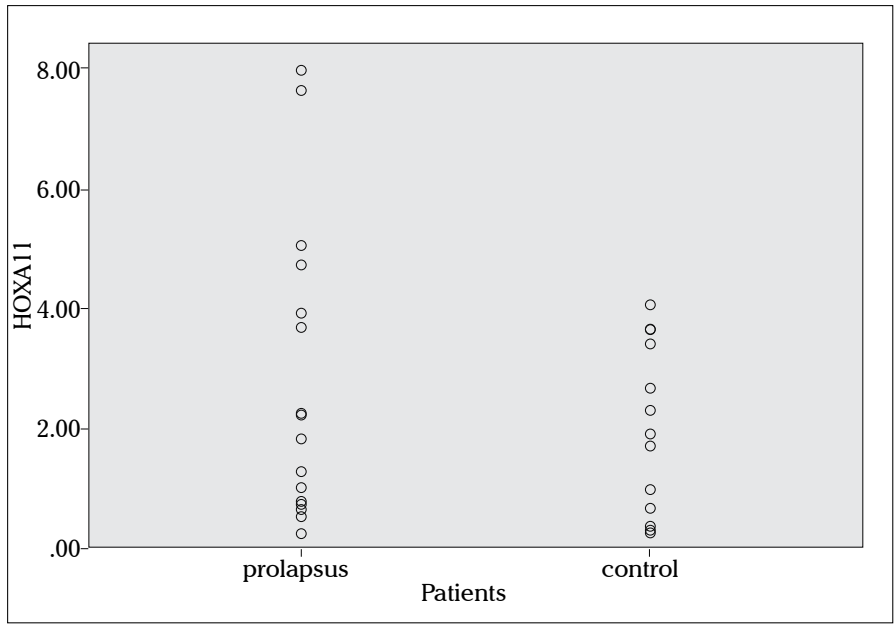

Figure 2. HOXA11 levels in USLs from women with and without POP

ogy of POP $(5,35,36)$. There are several studies related to MMP 2 expression in the uterosacral ligaments of patients with POP. Phillips et al. (6) compared tissue markers of collagen metabolism in uterosacral ligaments with those in vaginal tissue in women with uterine prolapse. They found elevated MMP activity in the vaginal skin of women, but they found no significant differences in the uterosacral ligaments of these women. In addition to this, Chen $\mathrm{BH}$ et al. (37) investigated quantitative mRNA expression of MMP-1, MMP-2, MMP-9, and their inhibitors - the tissue inhibitors of metalloproteinases TIMP-1, TIMP-2, and TIMP-3 - in vaginal wall tissue from women with stress urinary incontinence compared to continent controls. They did not find any difference in TIMP-2, TIMP-3, MMP-2, or MMP-9 mRNA expression between stress incontinent women and controls. Also, Strinic T et al. (38) investigated MMP-1 and matrix MMP-2 immunohistochemical expression in uterosacral ligament biopsies from women with pelvic organ prolapse (POP) and controls with normal pelvic support. The authors found a significant increase in MMP 1 immunohistochemical expression but no difference in immunohistochemical expression of MMP 2 between women with POP and those without. On the other hand, Gabriel et al. (5) demonstrated that MMP-2 expression was directly related to the presence of POP, rather than to age or parity. In a study by Jackson et al. (36), total collagen content, solubility, and turnover were determined by matrix metalloproteinase activity in the vaginal epithelium of patients with POP. They found that a reduction in total collagen content and solubility was associated with pelvic prolapse. There was also a significant elevation in collagenolytic activity, demonstrated by higher levels of MMP-2 and MMP-9. In the current study, we found that MMP-2 expression was increased in uterosacral ligament tissue from patients with prolapse ligaments. As mentioned above, there are some studies on this subject, and the results are contradictory. Referring to the pathophysiology of these diseases, these changes in the level of MMP2 can be expected.

With respect to gene expression of HOXA11, there are some studies about USL and POP in the literature. Firstly, Connell et al. (15) compared expression of HOXA11, collagen type 1, colla- 
gen type 3, MMP2, and MMP9 in USLs of women with and without POP. They demonstrated that expression of HOXA11 and both collagens dramatically decreased, while MMP2 increased in women with POP. In a second study, Connell et al. (4) demonstrated a decrease in the expression of HOXA11 and cellularity in women with POP. The authors suggested that functional development or repair of the USL might be deteriorated by deficiency of HOXA11 signaling after trauma in susceptible women. In another study, Ma Y et al. (16) reported the development of a mouse model of in vivo HOXA11 silencing within the female genital tract with abrogated gene effects on interstitial collagens and the gelatinase class of matrix metalloproteinases. They concluded that the results suggest a mechanism for the weakening of pelvic floor support in women, in that decreased HOXA11 gene expression can be associated with decreased collagen and increased MMP2 expression in the uterosacral ligaments of women with pelvic organ prolapse. In contrast, we did not find any decrease in expression of HOXA11 in USLs of patients with POP. Although Connel et al. $(4,15)$ showed an association between HOXA11 gene expression and the POP in their studies, we were unable to get the same result. Studies about the gene expression of HOXA11 and MMP2 are summarized in the Table 2 . As can be seen from the table, there are no sufficient data and consensus on this issue. For this reason, to clarify this topic, new studies are needed. Also, gene expression may vary between communities; thus, the results of this study may be different for every population.

This study has several limitations. First of all, our study population has a limited number of patients versus other studies in the literature. Secondly, we studied only uterosacral ligaments of patients for two parameters. This study could be done with other parameters (such as MMP9, collagen 1 and 3, or HOXA 10). In conclusion, we demonstrated that MMP2 expression was significantly higher in patients with POP. On the other hand, HOXA11 expression was not different between the groups. As mentioned above, many studies exist on this subject, but there are contradictory results. For this reason, controlled studies with larger series are needed.

Ethics Committee Approval: Ethics committee approval was received for this study from the Local Ethics Committee and Institutional Review Board of Zekai Tahir Burak Women's Health Education and Research Hospital and Başkent University Faculty of Medicine.

Informed Consent: Written informed consent was obtained from patients who participated in this study.

Peer-review: Externally peer-reviewed.

Author contributions: Concept - N.Y., F.I.S.; Design - N.Y., F.I.S., Y.K.T.; Supervision - N.Y., F.I.S.; Resource - N.Y., F.I.S.; Materials - N.Y., G.O.; O.A.; B.B.; Data Collection\&/or Processing - N.Y., Y.K.T., S.Y.; Analysis\&/or Interpretation - Y.K.T., F.I.S., ; Literature Search - N.Y., Y.K.T., S.Y.; Writing - N.Y., S.Y.; Critical Reviews N.Y., F.I.S.

Acknowledgements: The authors wish to thank Gözde Özer for the statistical analysis and Leyla Mollamahmutoglu for the study design.

Conflict of Interest: No conflict of interest was declared by the authors.

Financial Disclosure: The authors declared that this study has received no financial support.

\section{References}

1. Abramowitch SD, Feola A, Jallah Z, Moalli PA. Tissue mechanics, animal models, and pelvic organ prolapse: A review. Eur J Obstet Gynecol Reprod Biol 2009; 144 (Suppl 1): S146-58. [CrossRef]

2. Jelovsek JE, Maher C, Barber MD. Pelvic organ prolapse. Lancet 2007; 369: 1027-38. [CrossRef]

3. Mahendru R. Rectus fascia colpopexy for post-hysterectomy vault prolapse: A valid option. J Turk Ger Gynecol Assoc 2010; 11: 69-72. [CrossRef]

4. Connell KA, Guess Mk, Chen HW, Lynch T, Bercik R, Taylor HS. HOXA11 promotes fibroblast proliferation and regulates p53 in uterosacral ligaments. Reprod Sci 2009; 16: 694-700. [CrossRef]

5. Gabriel B, Waterman D, Hancke K, Gitsch G, Werner M, Tempfer C, zur Hausen A. Increased expression of matrix metalloproteinase 2 in uterosacral ligaments with pelvic organ prolapse. Int Urogynecol J 2006; 17: 478-82. [CrossRef]

6. Phillips $\mathrm{CH}$, Anthony F, Benyon C, Monga AK. Collagen metabolism in uterosacral ligaments and vaginal skin of women with uterine prolapse. BJOG 2006; 113: 39-46. [CrossRef]

7. Goepel C. Differential elastin and tenascin immunolabeling in the uterosacral ligaments in postmenopausal women with and without pelvic organ prolapse. Acta Histochemica 2008; 110: 204-9. [CrossRef]

8. Goepel C, Kantelhardt EJ, Karbe I, Stoerer S, Dittmer J. Changes of glycoprotein and collagen immunolocalizaton in the uterine artery wall of postmenopausal women with and without pelvic organ prolapse. Acta Histochemica 2011; 113: 375-81. [CrossRef]

9. Wu M-P. Regulation of extracellular matrix remodeling associated with pelvic organ prolapse. J Exp Clin Med 2010; 2: 11-6. [CrossRef]

10. Hendrix SL, Clark A, Nygaard I, Aragaki A, Barnabei V, McTiernan A. Pelvic organ prolapse in the women's health initiative: gravity and gravidity. Am J Obstet Gynecol 2002; 186: 1160-6. [CrossRef]

11. Bissell MJ, Hall HG, Parry G. How does the extracellular matrix direct gene expression? J Theor Biol 1982; 99: 31-68. [CrossRef]

12. Chung HW, Wen Y, Nezhat C, Woo BH, Polan ML. Matrix metalloproteinase-9 (MMP-9) and tissue inhibitor of metalloproteinase- 3 (TIMP-3) m-RNA expression in endometriosis: A rationale for endometriotic invasiveness. Fertil Steril 2001; 75: 152-9. [CrossRef]

13. Roebuck MM, Helliwell TR, Chaudhry IH, Kalogrianitis S, Carter S, Kemp GJ, et al. Matrix metalloproteinase expression is related to angiogenesis and histologic grade in spindle cell soft tissue neoplasms of the extremities. Am J Clin Pathol 2005; 123: 405-14. [CrossRef]

14. Creemers LB, Jansen ID, Docherty AJ, Reynolds JJ, Beertsen W, Everts V. Gelatinase A (MMP2) and cystein proteinases are essential for the degradation of collagen in soft connective tissue. Matrix Biol 1998; 17: 35-46. [CrossRef]

15. Connell KA, Guess MK, Chen H, Andikyan V, Bercik R, Taylor HS. HOXA11 is critical for development and maintenance of uterosacral ligaments and deficient in pelvic prolapse. J Clin Invest 2008; 118: 1050-5.

16. Ma Y, Guess M, Datar A, Hennessey A, Cardenas I, Johnson J, Connell KA. Knockdown of HOXA11 in vivo in the uterosacral ligament and uterus of mice results in altered collagen and matrix metalloproteinase activity. Biol Reprod 2012; 86: 100. [CrossRef] 
17. Bump RC, Mattiasson A, Bo K, Brubaker LP, DeLancey JO, Klarskov $\mathrm{P}$, et al. The standardization of terminology of female pelvic organ prolapse and pelvic floor dysfunction. Am J Obstet Gynecol 1996; 175: 10-7. [CrossRef]

18. Livak KJ, Schmittgen TD. Analysis of relative gene expression data using real-time quantitative PCR and the 2(-Delta Delta C(T)) method. Methods 2001; 25: 402-8. [CrossRef]

19. Bai SW, Choe BH, Kim JY, Park KH. Pelvic organ prolapse and connective tissue abnormalities in Korean women. J Reprod Med 2002; 47: 231-4.

20. Mant J, Painter R, Vessey M. Epidemiology of genital prolapse: observations from the Oxford Family Planning Association Study. Br J Obstet Gynaecol 1997; 104: 579-85. [CrossRef]

21. Buchsbaum GM, Duecy EE, Kerr LA, Huang LS, Perevich M, Guzick DS. Pelvic organ prolapse in nulliparous women and their parous sisters. Obstet Gynecol 2006; 108: 1388-93. [CrossRef]

22. Nikolova G, Lee H, Berkovitz S, Nelson S, Sinsheimer J, Vilain E, Rodríguez LV. Sequence variant in the laminin gamma 1 (LAMC1) gene associated with familial pelvic organ prolapse. Hum Genet 2007; 120: 847-56. [CrossRef]

23. Twiss C, Triaca V, Rodriguez LV. Familial transmission of urogenital prolapse and incontinence. Curr Opin Obstet Gynecol 2007; 19: 464-8. [CrossRef]

24. Janicke RU, Sohn D, Schulze-Osthoff K. The dark side of a tumor suppressor: Anti-apoptotic p53. Cell Death Differ 2008; 15: 959-76. [CrossRef]

25. Taylor HS, Vanden Heuvel GB, Igarashi P. A conserved Hox axis in the mouse and human female reproductive system: late establishment and persistent adult expression of the HOXA cluster genes. Biol Reprod 1997; 57: 1338-45. [CrossRef]

26. Taylor HS, Arici A, Olive D, Igarashi P. HOXA10 is expressed in response to sex steroids at the time of implantation in the human endometrium. J Clin Invest 1998; 101: 1379-84. [CrossRef]

27. Taylor HS, Igarashi P, Olive DL, Arici A. Sex steroids mediate HOXA11 expression in the human peri-implantation endometrium. J Clin Endocrinol Metab 1999; 84: 1129-35. [CrossRef]

28. Nagase $\mathrm{H}$. Activation mechanisms of matrix metalloproteinases. J Biol Chem 1997; 378: 151-60.

29. Woessner FJ. Matrix metalloproteinases and their inhibitors in con- nective tissue remodeling. FASEB J 1991; 75: 2145-54.

30. Stetler-Stevenson WG. Dynamics of matrix turnover during pathologic remodeling of the extracellular matrix. Am J Pathol 1996; 147: 1345-50.

31. Jones JL, Walker RA. Control of matrix metalloproteinase activity in cancer. J Pathol 1997; 183: 377-9. [CrossRef]

32. Kikkawa F, Nawa A, Shibata K, Obata NH, Tamakoshi K, Suzuki S, Mizutani S. The different stimulatory effect of normal tissues on the secretion of matrix metalloproteinases and their inhibitors by human ovarian cancer cells. Anticancer Res 1998; 18: 4323-8.

33. Nouvo GJ, MacConnel PB, Simsir A, Valea F, French DL . Correlation of the in situ detection of polymerase chain reaction-amplified metalloproteinase complentary DNAs and their inhibitors with prognosis in cervical carcinoma. Cancer Res 1995; 55: 267-75.

34. Vaisanen A, Tuominen H, Kallioinen M, Turpeenniemi- Hujanen T. Matrix metalloproteinase-2 (72 kD type IV collagenase) expression occurs in the early stager of human melanocytic tumor progression and may have prognostic value. J Pathol 1996; 180: 283-9. [CrossRef]

35. Tokuraku M, Sato H, Murakami S, Okada Y, Watanabe Y, Seiki M. Activation of the precursor of gelatinase A/72 kDa type IV collagenase/MMP-2 in lung carcinomas correlates with the expression of membrane-type matrix metalloproteinase (MT1-MMP) and with lymph node metastasis. Int J Cancer 1995; 64: 355-9. [CrossRef]

36. Jackson SR, Avery NC, Tarlton JF, Eckford SD, Abrams P, Bailey AJ. Changes in metabolism of collagen in genitourinary prolapse. Lancet 1996; 347: 1658-61. [CrossRef]

37. Chen BH, Wen Y, Li H, Polan ML. Collagen metabolism and turnover in women with stress urinary incontinence and pelvic prolapse. Int Urogynecol J Pelvic Floor Dysfunct 2002; 13: 80-7. [CrossRef]

38. Strinic T, Vuliac M, Tomic S, Capkun V, Stipic I, Alujevic I. Matrix metalloproteinases-1, -2 expression in uterosacral ligaments from women with pelvic organ prolapse. Maturitas 2009; 64: 132-5. [CrossRef]

39. Wieslander CK, Marinis SI, Drewes PG, Keller PW, Acevedo JF, Word RA. Regulation of elastolytic proteases in the mouse vagina during pregnancy, parturition, and puerperium. Biol Reprod 2008; 78: 521-8. [CrossRef] 